\title{
Expounding the Place of Legal Doctrinal Methods in Legal-Interdisciplinary Research
}

\author{
Experiences with Studying the Practice of Independent Accountability Mechanisms at \\ Multilateral Development Banks
}

\begin{abstract}
Andria Naudé Fourie*
\end{abstract}
\begin{abstract}
There is a distinct place for legal doctrinal methods in legalinterdisciplinary research methodologies, but there is value to be had in expounding that place - in developing a deeper understanding, for instance, of what legal doctrinal analysis has to offer, wherein lies its limitations, and how it could work in concert with methods and theories from disciplinary areas other than law. This article offers such perspectives, based on experiences with an 'advanced' legal-interdisciplinary methodology, which facilitates a long-term study of the growing body of practice generated by citizen-driven, independent accountability mechanisms (IAMs) that are institutionally affiliated with multilateral development banks. The article demonstrates how legal doctrinal methods have contributed towards the design and development of a multipurpose IAM-practice database. This database constitutes the analytical platform of the research project and also facilitates the integration of various types of research questions, methods and theories.
\end{abstract}

Keywords: legal doctrinal methods, legal interdisciplinarity, multilateral development banks, interdependent accountability mechanisms, database

\section{Introduction}

There is a distinct place for legal doctrinal methods in legal-interdisciplinary research methodologies, but there is value to be had in expounding that place - in developing a deeper understanding, for instance, of what legal doctrinal analysis has to offer, wherein lies its limitations, and how it could work in concert with methods and theories from disciplinary areas other than law. Such insights might strengthen our efforts to design 'advanced' legal-interdisciplinary research methodologies, ${ }^{1}$

Research Associate, Erasmus University Rotterdam, School of Law.

1. See M. Siems, 'The Taxonomy of Interdisciplinary Legal Research: Finding a Way Out of the Desert', 7 Journal of Commonwealth Law and Legal Education 5 (2009), describing 'advanced' legal-interdisciplinary research methodologies as approaches that address both 'legal and non-legal questions' and integrate "'scientific" methods' as well as nonlegal theory 'into legal thinking'. in particular, and to deploy such methodologies in transnational regulatory governance research contexts ${ }^{2}$ where the need for and place of legal normativity are often contested - or as Orford puts it, where law, 'as a source of constraints on the abuses of hegemonic power' finds itself at 'the limits of modern political organization'. ${ }^{3}$

This article aims to contribute to the development of such insights. The perspectives offered here are based on the author's experiences with designing and deploying an advanced legal-interdisciplinary methodology underlying a long-term research project. The project studies the growing body of practice generated by citizen-driven, independent accountability mechanisms (IAMs) that are institutionally affiliated with multilateral development banks (MDBs), such as the World Bank's

2. Referring to a 'concept [that] has become a widely used analytical perspective for describing the conduct of world affairs in many disciplines' and that has become known by different designations and associated with different definitions, including 'global governance' (see A. Von Bogdandy, P. Dann \& M. Goldmann, 'Developing the Publicness of Public International Law: Towards a Legal Framework for Global Governance Activities', in A. Von Bogdandy, R. Wolfrum, J. Von Bernstorff, P. Dann \& M. Goldmann (eds.), The Exercise of Public Authority by International Institutions: Advancing International Institutional Law (2010) 3, at 7), 'global regulatory governance' (see Kingsbury, below n. 15), and 'post-national governance' (see N. Krisch, Beyond Constitutionalism: The Pluralist Structure of Postnational Law (2010), at 4-6). As defined here, transnational regulatory governance refers to governance and regulation 'beyond the State' - because it concerns the 'activities, institutions, actors or processes that cross at least one national border', and typically involves 'actors other than national governments'. (See T. Hale and D. Held, 'Editors' Introduction: Mapping Changes in Transnational Governance', in T. Hale and D. (eds.), Handbook of Transnational Governance (2011) 1, at 5.)

3. See A. Orford, 'A Jurisprudence of the Limit', in A. Orford (ed.), International Law and Its Others (2006) 1, at 1-31. On the recognition of the need for legal normativity as basis for the construction of legal systems, see e.g. J. Brunnée and S. Toope, Legitimacy and Legality in International Law (2010), at 7-55. 
Inspection Panel. ${ }^{4}$ The article focuses on the place occupied by legal doctrinal analysis regarding a particular aspect of the research methodology, namely: the design and development of a multi-purpose IAM-practice database ('IAM-practice database' or 'database'). ${ }^{5}$

Section 2 of the article contextualises this discussion by situating IAMs in the particular transnational regulatory governance context in which they operate - that is, the transnational development context. Section 3 provides an overview of the research project and its underlying methodology, while emphasising aspects related to the IAM-practice database.

Section 4 explains the role of legal doctrinal analysis with respect to the design and development of the IAMpractice database. Section 5 concludes the discussion by reflecting on the significance of the experiences shared in this article - not only for the design and deployment of advanced legal-interdisciplinary research methodologies but also for deepening our understanding of the place of law in transnational regulatory governance contexts.

Before proceeding with this discussion, however, it is necessary to clarify a few assumptions and explain the core concepts underlying this article.

\subsection{Clarifying Basic Assumptions and Core Concepts}

This article assumes that its primary audience is legal scholars engaged (or interested) in conducting legalinterdisciplinary research, although the experiences shared here can certainly be of broader interest. This assumption, however, has implications for the content included in this article and, especially, how it is presented.

For instance, the article further assumes that legal scholars are generally unfamiliar with the terminology, methods and theories employed in the disciplinary areas involved in database design and development; hence,

4. On the World Bank's Inspection Panel, see <http://go.worldbank.org/ 7RCPYOFOCO >. Other IAMs included in the project's scope are the IFC and MIGA's Compliance Advisory Ombudsman (<http://www.caoombudsman.org/>), the AfDB's Independent Review Mechanism (<http://www.afdb.org/en/about-us/structure/independent-reviewmechanism/>), the ADB's Accountability Mechanism (<http://www. adb.org/site/accountability-mechanism/main $>)$, the IADB's Independent Consultation and Investigation Mechanism (<http://www.iadb. org/en/mici/independent-consultation-and-investigation-mechanismicim,1752.html>) and the EBRD's Project Complaints Mechanism (<http://www.ebrd.com/pages/project/pcm.shtml>) (all websites, last visited 31 October 2015).

5. Also note, examples of legal-interdisciplinary approaches in public international law remain sparse - e.g. there is only one contribution on 'law' in The Oxford Handbook of Interdisciplinarity (see M. Averill, 'Law,' in R. Frodeman, J.T. Klein \& C. Mithcham (eds.), The Oxford Handbook of Interdisciplinarity (2010), at 522); whereas the American International Law Journal's 'Symposium on Method in International Law' contains only one contribution that employs a 'purposefully interdisciplinary approach' (see 3 American Journal of International Law, at 291 (1999)); and in Research Methods for Law, the only contribution related to international legal research focuses primarily on state actors and the conventional sources of international law, whereas no mention is made of the role of legal-interdisciplinary approaches in this contribution (see S. Hall, 'Researching International Law', in M. McConville and W. Hong Chui (eds.), Research Methods for Law (2007), at 181. the 'technical' aspects of the discussion are kept to a minimum whereas the focus falls on the principles underlying the design and development of the database in question.

In fact, an important lesson derived from the experiences shared in this article is that deep technical skills are not a prerequisite for legal scholars to engage in the type of research described here. And this is not only because technical aspects can be delegated or outsourced to competent individuals. The lesson, instead, is that an intermediate level of proficiency with standard software such as MS Excel as well as a sound understanding of the principles behind key theoretical concepts and analytical tools employed in an area such as IT project management, ${ }^{6}$ for instance, can be decidedly effective - not to mention, cost efficient.

The article also assumes that legal scholars (including many of those specialising in public international law) are not as familiar with the wide range of independent accountability mechanisms operating at the international (or transnational) level than they are with international, regional, and national judicial institutions; nor are they as familiar with the development-lending operations of MDBs than they typically are with the operations of international institutions such as the United Nations. ${ }^{7}$ Hence, Section 2 provides more background detail than what might typically be expected in an article focusing on methodology.

As to the meaning of legal doctrinal research or scholarship, this article considers its activities as including the 'study, description, explanation and analysis' of the '(conflicting) underlying values, presuppositions and principles' contained in 'current positive law'. ${ }^{8}$ The principle purpose of legal doctrinal research, moreover, is usually to provide explicit normative comment ('how things should be') in order to formulate 'needed proposals for improvement'. ${ }^{9}$ Whereas legal doctrinal analysis employs, in essence, the same analytical and conceptual tools - methods - that 'abundantly' serve 'judges', namely: 'textual analysis', 'practical argumentation' as well as principled or structured 'reasoning' ${ }^{10}$
6. See e.g. J.L. Brewer and K.C. Dittman, Methods of IT Project Management, 2nd edn. (2008); and Project Management Institute, A Guide to the Project Management Body of Knowledge, 5th edn. (2013).

7. I am not alone in making this observation - see e.g. D.D. Bradlow and D. Hunter (eds.), International Financial Institutions and International Law (2010), remarking (at xxviii-xxix) that it is 'striking how little attention has been paid to the international legal issues relating to the operations of the International Monitory Fund, the World Bank Group, and the regional development banks ...'.

8. J. Vranken, 'Exciting Times for Legal Scholarship', 2 Recht en Methode in Onderzoek en Onderwijs 42, at 43 (2012).

9. Id.

10. Id., at 43-4. Also see Taekema's comment at note 126 
Current positive lam, in turn, refers to legal norms ${ }^{11}$ but these norms can be 'written and unwritten' and can originate from formal and informal norm-creation processes. ${ }^{12}$ Insofar as public international law is concerned, its norms are often captured in atypical 'forms of written sources such as reports, documents, explanations, protocols, and papers', and also have 'more unwritten' and informal - 'law that othe[r]' areas of law. ${ }^{13}$

In other words, while the article recognises the 'conventional' sources of 'current positive [public international] law' (as set out in Article 38(1) of the Statute of the International Court of Justice) ${ }^{14}$ it also considers the wide array of 'concoctions' of 'formal and informal instruments' as being part of 'current' - and emerging 'positive law'. ${ }^{15}$ Grounded in an 'interactional account' of public international law (as reflected, notably, in the scholarship of Brunnée and Toope), ${ }^{16}$ the IAM-practice research project is specifically interested in the norms that emerge from the 'contested terrain in the no-man's

11. I.e. as opposed to non-legal or social norms. Also note, this article employs Toope's argument that '[t]he category of 'norm' is inclusive and general. A norm may be vague or specific - it may mean a widespread social practice, a social prescription, a legal principle articulated to shape the evolution of a regime, or a precise legal rule. The common core of the concept of 'norm' is that the desideratum contained in the norm is intended to influence human conduct. Note the word 'influence': norms do not necessarily determine human action. They help to shape behaviour, but they rarely if ever dictate it. Since norms operate in many different ways, they relate to the concepts of formality and informality differentially as well. Norms can be formal rules of law, but they can also be informal social guides to proper conduct.' See $\mathrm{S}$. Toope, 'Formality and Informality', in D. Bodanksy, J. Brunnée \& E. Hey (eds.), The Oxford Handbook of International Environmental Law (2007) 107, at 107

12. See Vranken, above n. 8, at 43. On the distinction between 'formal' and 'informal' norms and of the significance of this distinction in international law, see e.g. Toope, above n. 11, at 107 (arguing that 'norms can be informal and precise as well as informal and vague'; which is to say, 'formality' is not an appropriate test for the existence of non-existence of law'). For a contrasting view on the importance of formality in public international law, see in general J. D'Aspremont, Formalism and the Sources of International Law: A Theory of the Ascertainment of Legal Rules (2011)

13. See Vranken, above n. 8 , at 43

14. I.e. 'international conventions', 'international custom', 'the general principles of law recognised by civilised nations', and (as 'subsidiary means' for establishing the 'rules of law', 'judicial decisions', and 'the teachings of the most highly qualified publicists of the various nations'. For a discussion of the conventional sources of public international law, see e.g. M.N. Shaw, International Law, 6th edn. (2008), at 70-127.

15. B. Kingsbury, 'Global Administrative Law in the Institutional Practice of Global Regulatory Governance', in H. Cissé, D.D. Bradlow \& B. Kingsbury (eds.), The World Bank Legal Review: International Financial Institutions and Global Legal Governance (2012), e-Book.

16. See J. Brunnée and Toope, Legitimacy and Legality in International Law: An Interactional Account (2010). The authors explain (Id., at 5-55) that their 'international account of international law' has been based in the jurisprudence of Lon Fuller as well as in constructivist thinking employed in the area of international relations. The authors argue (Id., at 22-4) that law is 'best viewed' as involving 'continuing challenge rather than as a finished project' since it is 'formed and maintained through continuing struggles of social practice' and 'is the work of its everyday participants', who engage in 'a continuous effort to construct and sustain a common institutional framework to meet the exigencies of social life in accordance with certain ideals'. Moreover, legal norms can be distinguished from non-legal or social norms by employing 'criteria' that assess their relative degrees of 'legality' and 'obligation' (Id.). land between international law and politics', and also in the actors involved in the application and enforcement of these norms. ${ }^{17}$

Interdisciplinarity describes research approaches that facilitate 'the appropriate combination of knowledge from many different specialities' - whereas 'knowledge' might refer to either theory or methods, or to both. ${ }^{18}$ This article views the primary purpose of an interdisciplinary approach (or, the principle motivating factor for employing such an approach) as 'problem solving in the real world'. ${ }^{19}$ Interdisciplinary approaches, despite their challenges, are well equipped to facilitate inquiry that can 'shed new light on ... actual problem[s]'. ${ }^{20}$ Therefore, the research methodology that forms the subject of this discussion fits within the broader 'transdisciplinary research' (TR) school of thought, which 'aims at better fitting academic knowledge production to societal needs for solving, mitigating, or preventing problems'. ${ }^{21} \mathrm{TR}$ is concerned with developing and employing theory and analytical methods that might aid interdisciplinary researchers in

grasp[ing] the relevant complexity of a problem, taking into account the diversity of both everyday and academic perceptions of problems, linking abstract and case-specific knowledge, and developing descriptive, normative and practical knowledge for the common interest. ${ }^{22}$

Legal interdisciplinarity, finally, describes a range of different approaches that obtain 'input' from disciplines other than law, but where such 'input' 'serves', in essence, 'as a necessary contribution to ... legal argu-

17. Toope, above n. 11, at 107. Also see C. Chinkin, 'Normative Development in the International Legal System', in D. Shelton (ed.), Commitment and Compliance: The Role of Non-Binding Norms in the International Legal System (2000) 21, at 23 (n. 13): “[T]here is a "brave new world of international law" where "transnational actors, sources of law, allocation of decision function and modes of regulation have all mutated into fascinating hybrid forms. International Law now comprises a complex blend of customary, positive, declarative and soft law".' Chinkin notes, however: 'Current debates about the forms and functions of international law-making are a continuation of long-standing tensions between those who assert the paramountcy of state consent and those who urge limitations on state action in favour of international regulation.' (Id., at 21). For an overview of the major arguments in these jurisprudential debates, see e.g. B. Kingsbury, 'The Concept of Compliance as a Function of Competing Conceptions of International Law', 19 Michigan Journal of International Law 345, at 348-67 (1997-1998); and I. Scobbie, 'Wicked Heresies or Legitimate Perspectives? Theory and International Law,' in M.D. Evans (ed.), International Law, 2nd edn. (2006) 83, at 83-156

18. G. Brewer, 'The Challenges of Interdisciplinarity', 32 Policy Sciences 327 (1999), at 328; and see Siems, above at n. 1.

19. See G. Hirsch Hadorn, C. Pohl, \& G. Bammer, 'Solving Problems through Transdisciplinary Research', in R. Frodeman, J.T. Klein \& C. Mithcham (eds.), The Oxford Handbook of Interdisciplinarity (2010) 431, at 431.

20. See Brewer, above n. 18, at 328. The author adds (at $/ d$.): 'In notably effective efforts, the combination of disciplines adds value: the total is more interesting than the sum of the individual contributions or parts'.

21. Hirsch Hadorn et al., above n. 19, at 431.

22. Id. 
ments'. ${ }^{23}$ Different legal-interdisciplinary approaches have been conceptualised as a continuum that envisages relative degrees of integration between 'law' and 'nonlegal disciplines'. The legal-interdisciplinary methodology described in this article might be described as 'auxiliary', ${ }^{24}$ 'intermediate' ${ }^{25}$ - or, positioned towards the middle-range of the continuum. However, as a research methodology facilitating long-term interdisciplinary inquiry (here, described as 10 years or more), it could also be argued that the methodology is progressively moving towards the 'integration' end of the spectrum, as the research project increasingly considered questions that are not strictly 'related to or affected by the law'. ${ }^{26}$

\section{Independent Accountability Mechanisms at Multilateral Development Banks, in Transnational Regulatory Governance Context}

The development-lending operations of multilateral development banks are described as a form of transnational regulatory governance for a number of reasons - a few of which will be highlighted here. For example,
MDB development-lending operations ${ }^{27}$ involve a wide range of state and non-state actors - including individuals ('project-affected people') ${ }^{28}$ - participating (in various capacities) in the activities, governance structures, and processes surrounding development projects financed (or co-financed) by MDBs. These activities, structures, and processes, in turn, cut across the international, regional, national as well as sub-national ('local') levels. In addition, MDB development-lending operations involve various (intersecting) normative systems that are both legal and non-legal ('social') in nature ${ }^{29}$ which also operate at (and, as some argue, across) the international, regional, national, and subnational ('local') levels. ${ }^{30}$

Different forms of transnational regulatory governance, moreover, share core characteristics. These include, for example, a shift from formal to informal governance and regulatory arrangements, structures, and processes which means that the distinction between what is considered 'formal' and 'informal' often becomes ambiguous. ${ }^{31}$ In addition, conventional systems of categorisation that have long been employed to differentiate between, for instance, different types of actors and functions ('public' versus 'private' sector), levels of governance ('international' versus 'national'), and types of normative systems (non-legal ('social') versus 'legal'), tend to lose their functional value when employed in transnational regulatory governance contexts. ${ }^{32}$ As a result of this 'flattening of the difference between various categories', 'a multitude of formal and informal connections [are] taking the place of what once were relatively clear rules and categories'. ${ }^{33}$

Characteristics such as these have various consequences. Of particular significance from a political-legal perspec-

27. Note: MDB development-lending operations include the activities involved in a typical 'project cycle' of MDB-financed development projects, situated in MDB borrower-member states. An MDB project cycle usually consists of the following stages: project identification, project design and appraisal, approval and financing, project implementation, closure and post-implementation review. See e.g. the World Bank's project cycle, available at: <http://go.worldbank.org/DT9OOK71V0> (last visited 30 October 2015). Examples of prominent MDBs include the World Bank Group (IBRD, IDA, IFC, MIGA, and ICSID), the InterAmerican Development Bank (IABD), Asian Development Bank (ADB), European Bank for Reconstruction and Development (EBRD), and the African Development Bank (AfDB). For examples of different forms of transnational regulatory governance, see in general T. Hale and D. Held (eds.), Handbook of Transnational Governance (2011); and K.E. Davis, A. Fisher, B. Kingsbury \& S. Engle Merry (eds.), Governance by Indicators: Global Power through Quantification and Rankings (2012).

28. I.e. a term of art used in MDB development-lending operations, referring to individuals affected by the design and implementation of an MDB-financed development project. Note, this impact might be positive, where these individuals stand to benefit from the project (in which case they would also be referred to as 'project beneficiaries'); or negative, where the project is (likely) to result in adverse environmental, economical or social effects within the project area.

29. And see above n. 11.

30. On the phenomenon of intersecting normative systems in an emerging 'postnational' legal and political order, see in general Krisch, above n. 2 .

31. See Von Bogdandy et al., above n. 2, at 7 and 9. For criticism of the 'growing use of non-formal law-ascertainment criteria', see D'Aspremont, above n. 12, at 221-3.

32. Krisch, above n. 2 , at 4 .

33. Id. 
tive, for example, are the resulting challenges of identifying 'unilateral' or 'non-authoritative acts'. ${ }^{34}$ In the context of MDB development-lending operations where 'public authority' 35 or power is exercised by international organisations (the MDBs), MDB-donor and borrower states, as well as by the public and private sector (and, on occasion, civil society) entities acting as project implementing agencies - the challenges involving the identification of 'non-authoritative' acts and the attribution of accountability (not to mention, of legal liability and responsibility), ${ }^{36}$ are exacerbated by the fact that MDBs have steadily increased the scope of their development agendas over the past decades. ${ }^{37}$

Moreover, as Klabbers points out, the exercise of public authority by a wide range of actors 'can also take on all sorts of legal and quasi-legal forms'. ${ }^{38}$ And, while this 'process of 'legal pluralization' is underway in various manifestations (diffusion of actors as well as forms)', it is also 'accompanied by a broader normative pluralization' - which results in a situation where it is no longer immediately evident (presuming it ever was) that legal authority is the sort of authority to strive for'. ${ }^{39}$ Hence, as Kingsbury comments, '[1] aw contributes appreciably, but generally only in limited ways, alongside political, economic, social, and historical factors

... in explaining why certain institutions exist in the global administrative space with particular memberships and structures, why these have the mandates and decision rules they do, and why other institutions, mandates, or rules do not exist. ${ }^{40}$

34. Von Bogdandy et al., above n. 2, at 4.

35. Von Bogdandy et al., above n. 2, at 5 (arguing that 'any kind of governance activity by international institutions,' 'be it administrative or intergovernmental, should be considered as an exercise of international public authority if it determines individuals, private associations, enterprises, states, or other public institutions'. (Emphasis in original.)

36. On the distinction between these concepts, see e.g. the conceptual work of the International Law Association (ILA) on the accountability of international organisations (IOs). The ILA describes different forms (e.g. political, legal, administrative, financial) and levels of IO-accountability, i.e.: first level: various 'forms of internal and external scrutiny and monitoring, irrespective of potential and subsequent liability and/or responsibility'; second level: 'tortious liability for injurious consequences arising out of acts or omissions not involving a breach of any rule of international and/or institutional law'; and third level: 'responsibility arising out of acts or omissions which do constitute a breach of a rule of international and/or institutional law.' (See International Law Association, Report of the Seventy First Conference, Berlin (2004), available at: <http://www.ila-hq.org/en/publications/order-reports.cfm>, at 5-6 (last visited 31 October 2015)). Note, IAM-practice would constitute an example of 'first level accountability' that combines various forms of accountability.

37. See e.g. in general J.W. Head, 'For Richer or for Poorer: Assessing the Criticisms Directed at the Multilateral Development Banks', 52 The University of Kansas Law Review, 241 (2003-2004); and D.D. Bradlow and C. Grossman, 'Limited Mandates and Intertwined Problems: A New Challenge for the World Bank and the IMF', 17 Human Rights Quarterly 411 (1995).

38. J. Klabbers, 'Setting the Scene', in J. Klabbers, A. Peters, \& G. Ulfstein, The Constitutionalization of International Law (2009) 12, at 12-4.

39. Id.

40. See Kingsbury, above n. 15.
Or, as Orford argues, 'a renewed public interest in cosmopolitan legality' transpired 'at the same moment as a perceived crisis of relevance [of] existing international law and institutions' ${ }^{41}$ In other words, the 'questions to which international law is expected to offer an answer' including the accountability, legal liability, and responsibility of international organisations - 'are some of the most important, vital and intriguing questions of our time'; yet, there is a persistent perception that 'international law as a discipline has lost its capacity to provide a compelling understanding of what is at stake when these questions arise'. ${ }^{42}$ This conundrum compels international legal scholars, aided by the theories and methods from non-legal disciplines, to 'think about what happens to law at the limits of modern political organization'. ${ }^{43}$

\subsection{MDB Responses to Concerns about Accountability: The Operational Policies and Citizen-Driven IAMs}

Over the past few decades, MDBs, with the World Bank Group blazing the trail, have responded to concerns about their accountability in a number of ways. ${ }^{44}$

Notably, MDBs have established internal normative frameworks to guide their development-lending operations. These operational policy framemorks incorporate informal best practices (norms that are recommended but not obligatory) as well as formal operational policies and procedures (norms that are compulsory for MDB management and staff, and, to the extent that these norms are incorporated in the credit/loan agreement, also for borrowers). ${ }^{45} \mathrm{~A}$ critical part of these operational policy frameworks includes the safeguard policies, which are
41. See Orford, above n. 3.

42. Id.

43. Id.

44. Note, another prominent response not discussed here concerns reforms of MDB governance structures - in this regard, see e.g. N. Woods, 'Making the IMF and the World Bank More Accountable', 77 International Affairs 1, 83 (2001); Head, above n. 37; and see D.D. Bradlow, 'The Reform of the Governance of the IFls: A Critical Assessment', in $\mathrm{H}$. Cissé, D.D. Bradlow \& B. Kingsbury (eds.), The World Bank Legal Review: International Financial Institutions and Global Legal Governance (2011), e-Book.

45. For a comparative overview and analysis of World Bank (IDA and IBRD) and IFC operational policies, see e.g. D. Bradlow and A. Naudé Fourie, 'The Operational Policies of the World Bank and the International Finance Corporation Creating Law-Making and Law-Governed Institutions?', 10 International Organizations Law Review 3 (2014), at 3-80. For a discussion of how the MDBs incorporate their operational policies as 'conditionalities' in the credit/loan agreement, see e.g. L. Boisson de Chazournes, 'Policy Guidance and Compliance: The World Bank Operational Standards', in D. Shelton (ed.), Commitment and Compliance (2000) 281, at 289-90. Note, a credit/loan agreement entered between an MDB and a borrower member state is an international agreement (between an international organisation and a state), governed by international law - see e.g. D.D. Bradlow, 'International Law and the Operations of the International Financial Institutions', in D.D. Bradlow and D.B. Hunter (eds.), International Financial Institutions and International Law (2010) 1, at 11; and see D.A. Wirth, 'Commentary: Compliance with Non-Binding Norms of Trade and Finance', in D. Shelton (ed.), Commitment and Compliance (2000) 330, at 334. 
aimed specifically at managing environmental, social, and economic risks. ${ }^{46}$

The 'legal nature' of these operational policy frameworks remains a point of contention. Generally speaking, internal ('institutional') stakeholders argue that operational policies and procedures are internal documents with no legal features, ${ }^{47}$ while external ('public') stakeholders assert that these norms are becoming or have become a 'form of particularly potent institutional law'. ${ }^{48}$ Bradlow and Hunter conclude, for example, that the MDBs' operational policies and procedures 'at least' establish

a soft 'lex speciali' to govern their own operations in regard to their Member States. As [the MDBs] implement this soft law, it has the potential to raise expectations among the stakeholders in these operations who begin to expect the [MDBs] to comply with this soft law in their operation and to anticipate that they can hold the [MDBs] to account if they fail to comply with them .... ${ }^{49}$

A second response, which is of particular significance for this discussion, concerns the establishment of independent accountability mechanisms. These bodies are mandated to enforce the relevant operational policy frameworks and, through their functions of fact-finding, problem-solving, compliance review, policy advice, and monitoring, to strengthen the MDBs' management and governance structures. ${ }^{50}$

What makes these bodies unique, however, is the fact that they are citizen-driven - that is, they are mandated (usually, by the MDB's Board of Executive Directors) to receive claims directly from project-affected people and/or their authorised (civil society) representatives, concerning claims of actual or potential harm suffered as a result of the MDB's non-compliance with the relevant operational policy framework. ${ }^{51}$

In other words, the IAMs also provide affected individuals with an avenue of recourse as well as (at least) the potential for redress. ${ }^{52}$ Before the establishment of the

46. For a discussion of the 'evolution' of the World Bank's safeguard policies as the embodiment of the Bank's 'environmental and socially sustainable mandate,' see D. Freestone, The World Bank and Sustainable Development (2013), at 9-16, and 63-71.

47. See e.g. I.F.I. Shihata, The World Bank Inspection Panel: In Practice (2000), at 41-9; and see S. Schlemmer-Schulte, 'The World Bank Inspection Panel: A Record of the First International Accountability Mechanism and Its Role for Human Rights', 6 Human Rights Brief 1, at 1 (1999).

48. See J. Alvarez, International Organizations as Law-Makers (2005), at 235.

49. See Bradlow, above n. 45, at 26; Wirth, above n. 45, at 333-7; and see L. Boisson de Chazournes, 'The World Bank Inspection Panel: About Public Participation and Dispute Settlement', in T. Treves, M. Frigessi di Rattalma, A. Tanzi, A. Fodella, C. Pitea \& C. Ragni (eds.), Civil Society, International Courts and Compliance Bodies (2005) 187, at 191-2. For a discussion of the inclusion of international legal standards in the IFC's operational policies, see e.g. D. Bradlow and M. Chapman, 'Public Participation and the Private Sector: The Role of Multilateral Development Banks and the Evolving Legal Standards', 4 Erasmus Law Review 89 (2011).

50. For a discussion of the entire range of internal accountability mechanisms at the World Bank, see e.g. Shihata, above, n. 47, at 8-15.
World Bank's Inspection Panel in $1993,{ }^{53}$ project-affected people, who are in a 'non-contractual relationship' with MDBs, had no form of recourse or redress against $M D B s$ in instances where they have allegedly suffered actual or potential harm due to $M D B$ actions or inactions. ${ }^{54}$ The establishment of IAMs placed individuals for the first time in the history of public international law - in a 'legally relevant relationship' vis-à-vis an international organisation. ${ }^{55}$

That being said, the 'non-judicial' versus 'quasi-judicial' nature of these bodies remains a point of contention and is also related to debate about the legal nature of the MDBs' operational policy frameworks. ${ }^{56}$ The MDBs typically emphasise the non-judicial nature of these

51. See e.g. Inspection Panel Resolution (1993). Resolution No. IBRD 93-10/Resolution No. IDA 93-6, The World Bank Inspection Panel, 22 September 1993, para. 12. The World Bank's operational policy framework forms the Panel's only basis for review, and '[f]or purposes of this Resolution, 'operational policies and procedures' consist of the Bank's [binding] Operational Policies, Bank Procedures and Operational Directives, and similar documents issued before these series were started, and does not include [non-binding] Guidelines and Best Practices and similar documents or statements'. All World Bank operational policies and procedures are available at: <http://www.worldbank.org/ opmanual/> (last visited 31 October 2015).

52. Note, IAM-procedures can also be triggered from within the MDB (e.g. by an Executive Board member, or by the MDB president); however, IAM-practice consists almost entirely of claims filed by external parties.

53. For a history of the Inspection Panel's establishment, the first IAM of this kind, and which establishment led to similar developments at other MDBs, see e.g. Shihata, above, n. 47. For a comparative functional overview of prominent IAMs at MDBs, see e.g. D. Bradlow and A. Naudé Fourie, 'Independent Accountability Mechanisms at International and Regional Development Banks', in T.N. Hale and D. Held (eds.), Handbook of Innovations in Transnational Governance (2011), at 122.

54. Note, this situation is the result of structural deficiencies in the international legal system that are not easily remedied, i.e.: the (qualified) immunity of international institutions before domestic courts; limitations of legal standing before international judicial tribunals; and prevailing ambiguity about the international legal obligations of international organisations. In this regard, see e.g. D.D. Bradlow and D.B. Hunter (eds.), International Financial Institutions and International Law (2010), at xxv-xxix and 387-97. For a critical analysis of the immunity of international institutions before domestic courts, see e.g. A. Reinisch, International Organization before National Courts (2008). On the limitations of the international legal system in providing legal recourse and redress to individuals in a non-contractual relationship with international institutions, see in general J. Wouters, E. Brems, S. Smis \& P. Schmitt (eds.), Accountability for Human Rights Violations by International Organisations (2010).

55. See E. Hey, 'The World Bank Inspection Panel: Towards the Recognition of a New Legally Relevant Relationship in International Law', 2 The Hofstra Law \& Policy Symposium 61 (1997), at 61.

56. MDBs are concerned that claims filed at the IAMs might be used as a basis for challenging their qualified immunity before domestic courts as had occurred in at least one (unsuccessful) instance in the institutional history of the World Bank Inspection Panel - see e.g. Shihata's comments about the Argentina/Paraguay: Yacyretá case, above n. 47, at 122-4; and see Shihata's argument (Id., at 234) that 'a violation by the Bank of its policy, even if established by the [Inspection] Panel is not necessarily a violation of applicable law that entails liability for ensuing damages; and ... since the Panel is not a court of law, its findings on Bank violations cannot be taken ipso facto as a conclusive evidence against the Bank in [domestic] judicial proceedings'. Note, Ibrahim Shihata was a former World Bank Vice President and Group Legal Counsel. 
mechanisms ${ }^{57}$ whereas academic commentators (including this author) tend to view IAMs as 'hybrid' mechanisms with certain court-like features. ${ }^{58}$

As the growing number of different IAMs investigated a slowly but steadily increasing number of cases, ${ }^{59}$ researchers in the areas of public international law and political science underlined the potential for normative development - emanating from the 'dispute resolution triad' formed by the claimants, MDB management (the 'respondents'), and the IAM (with the MDB's Board of Executive Directors usually acting as final arbiter). ${ }^{60}$ Studying the practice of IAMs, therefore, could yield significant insights as to the content and scope of the international legal responsibilities of MDBs, which remain an ambiguous area. ${ }^{61}$

It could also help to clarify the place of law in transnational regulatory governance contexts because, while the

57. See e.g. Schlemmer-Schulte, above n. 47, arguing that the 'implementation of the Bank's policy standards in projects does not result in substantive rights that individuals in borrowing countries may claim against the Bank, nor does the Inspection Panel represent a legal remedy mechanism through which positions described in the Bank's policies or rights referred to in the Resolution could be enforced against the Bank'. Note, the author was Senior Counsel and Associate General Counsel/Special Advisor to the Senior Vice President and General Counsel of the World Bank, between 1995 and 2002. Also see M. Hansungule, 'Access to Panel - The Notion of Affected Party, Issues of Collective and Material Interest', in G. Alfredsson and R. Ring (eds.), The Inspection Panel of the World Bank: A Different Complaints Procedure (2001) 143, commenting (at 150) that while the Panel is clearly 'not a court of law and not even like a court of law', it is nevertheless significant that the Panel as well as 'Bank officials frequently like to stress this point as if to prove that it is in fact a kind of a court of law. The fact that it is not a court of law or like a court is sometimes denied so often by Bank staff as to suggest that this was in fact the idea behind its establishment'.

58. See e.g. L. Boisson de Chazournes, 'Compliance with Operational Standards - The Contribution of the World Bank Inspection Panel', in G. Alfredsson and R. Ring (eds.), The Inspection Panel of the World Bank: A Different Complaints Procedure (2001) 67, at 83-4; B. Kingsbury, 'Operational Policies of International Institutions as Part of the LawMaking Process: The World Bank and Indigenous Peoples', in G.S. Goodwin-Gill and S. Talmon (eds.), The Reality of International Law: Essays in Honour of lan Brownlie (1999) 323, at 332; K. Nathan, 'The World Bank Inspection Panel: Court or Quango?', 12 Journal of International Arbitration 135, at 137-8; and see in general A. Naudé Fourie, The World Bank Inspection Panel and Quasi-Judicial Oversight: In Search of the 'Judicial Spirit' in Public International Law (2009). For a discussion of how IAMs fit into Romano's 'taxonomy' of international rule of law bodies, see C.P.R. Romano, 'A Taxonomy of International Rule of Law Institutions', 2 Journal of International Dispute Settlement 241, at 247 (2011). But also see M. Van Putten, Policing the Banks: Accountability Mechanisms for the Financial Sector (2008), at xxiii. Van Putten (a non-lawyer and former Inspection Panel member) considers the fact that 'most studies about accountability mechanisms, compliance mechanisms, and review panels - and more specifically the Inspection Panel - have been done by lawyers', as both 'a hindrance and challenge'. (Id.)

59. For a statistical overview of cases filed at different IAM, see e.g. A. Naudé Fourie, The World Bank Inspection Panel Casebook (2014), at 604

60. See in general Kingsbury, above n. 58; see Bradlow and Naudé Fourie, above n. 45, at 59-62; Bradlow and Hunter, above n. 54, at 395-6; and see E. Suzuki and S. Nanwani, 'Responsibility of International Organizations: The Accountability Mechanisms of Multilateral Development Banks', 27 Michigan Journal of International Law 177 (2005-2006), at 225. On normative development occurring as a 'by-product' of 'triadic dispute resolution', see in general M. Shapiro and A. Stone Sweet, On Law, Politics, and Judicialization (2002).

61. See Bradlow and Hunter, above, n. 54, at xxv-xxix and 387-97. contribution of legal normativity may have been limited in the past, as Kingsbury argues, 'the roles of law are of rapidly growing in importance' since 'the stakes involved in [transnational regulatory governance] regimes are high.' ${ }^{62}$ Indeed, '[n]ew understandings of law and its roles are emerging ${ }^{\prime 63}$ in part because international organisations 'have increasingly sought to shore up their legitimacy, and to enhance the effectiveness of their regulatory activities, by applying to (and between) themselves procedural norms,' including 'transparency, participation, reasoned decision making, ... legality, and [the establish[ment] [of] mechanisms of review and accountability'. ${ }^{64}$

\section{The Research Project and Its Underlying Methodology}

The IAM-practice research project ('project'), therefore, set off by addressing legal questions. ${ }^{65}$ The project's initial 'dynamic hypothesis' '66 argued that there is a functional equivalence betmeen judicial institutions executing mandates of judicial reviem and citizen-driven IAMs at $M D B s$ executing mandates of fact-finding and compliance reviem.

This dynamic hypothesis provides the first hint of the place legal doctrinal methods came to occupy in the project's research methodology. If IAMs, reviewing the actions and omissions of MDBs against the normative framework constituted by the operational policies and procedures, are likened to courts executing mandates of judicial review, it would make sense to employ the same interpretative techniques and schemes used by judges and employed in 'legal [doctrinal] scholarship'. ${ }^{67}$

But the need for employing a legal-interdisciplinary approach also became clear during the early stages of the project. In fact, this need was illustrated quite forcibly by a cursory analysis of IAM-practice material, which demonstrates, for instance, that MDB developmentlending operations cut across various disciplinary areas and practice domains. Moreover, the notion of 'accountability' is multifaceted and different disciplines tend to

62. See Kingsbury, above n. 15

63. Id.

64. Id

65. Note, the project started in 2005 as a masters-level dissertation, expanded into a doctoral research project in 2007 , and continued as a postdoctoral research project during 2009-2015.

66. A 'dynamic hypothesis', which is informed by theory and observations drawn from practice, 'supports and informs' inquiry; but it does not treat theory 'as an illusive, sacred Truth'. (See M. Shields and N. Rangarajan, A Playbook for Research Methods: Integrating Conceptual Frameworks and Project Management (2013), at 1-11.) In this project, various dynamic hypotheses have been reflected as conceptual models (as illustrated in Section 3) that serve as 'useful tool[s] that organiz[e] inquiry connecting problem and data'. (Id., at 23-4.)

67. See Vranken, above n. 8, at 43-4. 
emphasise different aspects thereof. ${ }^{68}$ Hence, the project concluded that the issue of 'MDB-accountability' needs to be addressed by means of a legal-interdisciplinary approach. As the ILA argues, IO-accountability is 'not a notion which, for the sake of its operationality, is or has to be viewed as monolithic, calling for uniform and indiscriminate application' ${ }^{69}$ Simply put, 'such rigidity would not survive the complexities of international reality' ${ }^{70}$ Instead, our efforts to conceptualise and operationalise the accountability of international organisations have to maintain the 'delicate balance'

between preserving the necessary autonomy in decision-making for ... [international institutions] and responding to the need, both in the sphere of international law and international relations, to have these actors accountable for their acts and omissions. ${ }^{71}$

As the research project proceeded, it became increasingly clear that IAM-practice provides a unique window onto MDB development-lending operations that might also facilitate inquiry into matters that are not 'entirely legal', or that are merely 'law related'. For instance, IAM-practice demonstrates the complex dynamics between MDBs, borrowers, and project implementing agencies; the intricate trade-off decisions involved in 'balancing' economic, social, and environmental interests in order to realise the sustainable development objectives; as well as the tension among institutional performance areas aimed at meeting commercial objectives and those aimed at public objectives, including the avoidance and mitigation of social and environmental 'harm' or material adverse effects.

Interdisciplinary researchers are familiar with the challenges involving integration - that is, how do you fit different types of methods, theories, and research questions into a methodology so that it is not only coherent, but also so that its different components work together

68. See e.g. R. Mulgan, 'Accountability': An Ever-expanding Concept?', 78 Public Administration 555, at 555 (2000); and see J. Fox, 'Introduction: Framing the Inspection Panel', in D. Clark, J. Fox \& K. Treakle (eds.), Demanding Accountability: Civil-Society Claims and the World Bank Inspection Panel (2003) xi, at xii, arguing that accountability is an 'inherently relational' concept and its 'meaning [therefore] varies greatly depending on the actors involved (for example, contractual, corporate, and political accountability are all quite different).' As for '[t]he standards themselves', that is, 'what counts as compliance', Fox argues that both 'the scope and meaning of public accountability more generally, are all contested and shaped through political conflict.' (Id., emphasis in original.)

69. International Law Association, Report of the Sixty Eighth Conference, Taipei (1998), available at: <http://www.ila-hq.org/en/publications/ order-reports.cfm>, at 15-7 (last visited 31 October 2015). Also see Bradlow and Hunter, above n. 54, at 81.

70. $1 d$

71. International Law Association, Report of the Seventy First Conference, Berlin, (2004), available at: <http://www.ila-hq.org/en/publications/ order-reports.cfm>, at 5-6 (last visited 31 October 2015). On IOaccountability as a multifaceted concept, also see e.g. E. Brown Weiss, 'On Being Accountable in a Kaleidoscopic World', 104 American Society of International Law Proceedings 477, at 480 (2010). in such a way that the total can indeed be more - and 'more interesting' - than the sum of its parts?

In this project, two (closely related) mechanisms facilitate such integration: conceptual models ${ }^{73}$ (discussed in Section 4) and the IAM-practice database ('database'), which will be introduced in the remainder of this section.

\subsection{The IAM-Practice Database}

The IAM-practice database ${ }^{74}$ provides the project's analytical platform. It consists of five components, containing different types of data: ${ }^{75}$

1. A comparative institutional and functional overviem of IAM-mandates, functions, compositions, operating processes and procedures, as well as MDB operational policies. This component facilitates contextualisation, which is a critical analytical component during the initial stages of interdisciplinary and comparative research projects. ${ }^{76}$

2. A quantitative overviem, which supports descriptive statistical analyses of various quantifiable aspects concerning, for instance, MDB development-lending operations and claims filed at the IAMs. ${ }^{77}$

3. A descriptive IAM-case overviem, which provides a structured summary of all individual claims ('cases') filed at the IAMs - setting out key aspects

72. See Brewer, above n. 20. On challenges involving legal-interdisciplinary approaches, see e.g. Vick, above n. 25, at 185; and see in general Siems, above n. 1. Also see Hirsch Hadorn et al., above n. 19, at 443-8.

73. Conceptual models employed in legal scholarship have been described as 'neutral reference system[s] in the form of concepts' or 'abstract models derived in an inductive process from specific instances of realexisting law' (see O. Brand, 'Conceptual Comparisons: Towards a Coherent Methodology of Comparative Legal Studies', 32 Brooklyn Journal of International Law 405, at 436 (2007); and in other research contexts it has been described as 'system[s] of concepts, assumptions, expectations, beliefs, and theories that suppor[t] and informs your research' (see J. Maxwell, 'Designing a Qualitative Study', in L. Bickman and D. Rog (eds.), The Sage Handbook of Applied Social Research Methods (2009), at 222); or, as 'the way ideas are organized to achieve a research project's purpose' (see Shields and Rangarajan, above n. 66, at 24).

74. Database, as defined here, refers to a repository of various types of information ('data') that is organised in such a way so as to ensure 'ease and speed of search and retrieval' (see <http://www.thefreedictionary. com/database> (last visited 31 October 2015)).

75. Data is defined here as different types of '[f]acts that can be analyzed or used in an effort to gain knowledge or make decisions' (see <http:// www.thefreedictionary.com/data> (last visited 31 October 2015)).

76. Note, the data included in this component has been collected and configured by comparative (constitutional) law and legal doctrinal methods. On the importance of contextualisation in comparative legal studies, see e.g. A. Peters and H. Schwenke, 'Comparative Law beyond Post-Modernism', 49 International and Comparative Law Quarterly 800, at 801-802 (2000); and see T. Koopmans, Courts and Political Institutions: A Comparative View (2003), at 96-7. On the role of contextualisation in developing an understanding of the 'relevant complexity of a problem' in interdisciplinary or 'transdisciplinary problem-oriented' research, see Hirsch Hadorn et al., above n. 19, at 441.

77. Note, the data included in this component has been collected and configured by means of descriptive (as opposed to predictive or inferential) statistical methods. Descriptive statistics 'summarize the information in a collection of data', whereas inferential statistics 'provide predictions about a population, based on data from a sample of that population'. See A. Agresti and B. Finlay, Statistical Methods for the Social Sciences (2009), at 4. For examples of how this data has been employed, see Naudé Fourie, above n. 58, at 566-604 
of the case and covering each stage of the IAM-process. $^{78}$

4. An indexed overviem, consisting of recurring words and phrases in IAM-practice material (such as 'environmental impact assessment', 'indigenous people', 'poverty reduction', and 'hydro-electric power facility'). ${ }^{79}$

5. A qualitative overviem, consisting of recurring themes, problems - issues - extracted from IAMpractice material (such as the 'definition of indigenous people', the meaning of 'free and informed participation of indigenous peoples', the 'identification and quantification of project-affected people', and the 'diligent consideration of design alternatives'.

With the exception of component (2), which contains numeric data, the data in components (1), (3), (4), and (5) are text, sourced from: (1) MDB project documentation that is in the public domain $;^{80}$ (2) MDB operational policies; ${ }^{81}$ and (3) IAM-practice material. ${ }^{82}$ What further distinguishes component (5) is the fact that it involves a significant degree of interpretation. Hence, as Section 3 will discuss in more detail, legal doctrinal analysis played a prominent role in collecting and configuring the data contained in the issue overviem (component (5)).

Furthermore, components (1), (2), (3), and (4) reflect a 'data-driven' (or, 'bottom-up') approach - meaning, the database design has been influenced by the structure, format, and content of the data; whereas data collection and configuration involved the systematic processing of all data, recording only what has been identified.

A data-driven approach might therefore be compared to the proverbial search through a haystack - without, however, being given detailed instructions to find a needle, but simply to record all findings and place ('configure') them in appropriate data categories and sub-categories (e.g. 'hay' ['short', 'medium', and 'long stubs'], 'needles', and 'insects' ['ants', 'crickets', and 'grasshoppers']).

Component (5), by contrast, reflects a 'hypothesis-driven' (or, 'top-down') approach - meaning, a particular dynamic hypothesis (which, in terms of this project has,

78. For examples of how this data has been employed, see in general Naudé Fourie, above n. 58.

79. Note, the data collection process involved in this component have been partly automated; however, because of inconsistencies in the way terminology is used across the different IAMs and MDBs, and also due to the continuous institutional evolution of the IAMs, data has mostly involved 'human indexing' techniques. On the differences between 'human' and 'automated' indexing, see e.g. J.D. Anderson and J. PerezCarballo, 'The Nature of Indexing: How Humans and Machines Analyze Messages and Texts for Retrieval', 37 Information Processing and Management 231 (2001).

80. See e.g. the World Bank's project repository, at: <http://www worldbank.org/projects> (last visited 31 October 2015).

81. See e.g. the EBRD's operational policies at: <http://www.ebrd.com/ what-we-do/strategies-and-policies.html> (last visited 31 October 2015).

82. See e.g. the IFC/MIGA's Compliance Advisory Ombudsman's cases at: <http://www.cao-ombudsman.org/cases/> (last visited 31 October 2015). as noted, been expressed as various conceptual models $)^{83}$ informed the database design and facilitated the data collection and configuration process.

To extend the earlier metaphor: the dynamic hypothesis would inform and direct the inquiry to look for 'needles in particle areas of the hay stack', whereas legal doctrinal methods, as will be discussed in the remainder of the article, would assist with the identification and categorisation ('coding') of collected data. ${ }^{84}$ In other words, by employing legal doctrinal analysis, a 'thin piece of bent metal with one fairly sharp end' might be located in the haystack and, although the object would not conform to 'conventional needle-design', it could still be recorded under a relevant category that reflects its functional equivalence.

\section{The Place of Legal Doctrinal Analysis in Designing and Developing the IAM-Practice Database}

Legal doctrinal analysis occupied a place of prominence during the IAM-practice database's design and development stages - notably, with respect to the issue overviem component (5), which also forms the focus of the discussion in this section.

\subsection{Designing the Database: Legal Doctrinal Analysis Supporting Conceptualisation}

The database design stage consists of the following activities: identifying potential data sources; analysing the data format and content in the identified sources to gain an understanding of how the data might support different types of analyses; designing the data collection process (i.e. determining what data would be extracted from the identified sources, and how the data will be extracted); designing the data categorisation or coding process (i.e. deciding how the data will be categorised or sorted within the database) ${ }^{85}$ designing the data configuration process (i.e. determining how the data will be recorded, identifying the relationships between data sets and deciding how these relationships will be reflected within the database; ${ }^{86}$ and designing the data testing pro-

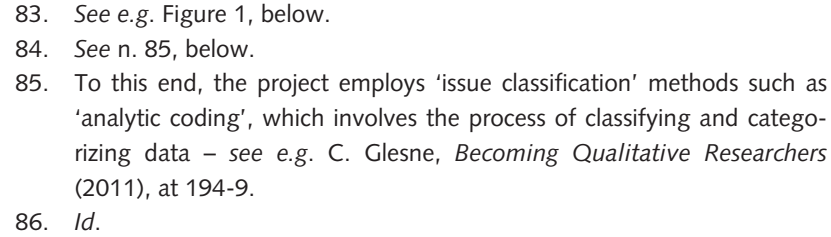


cess (i.e. determining what approach will be followed to ensure data quality). ${ }^{87}$

Because the issue component of the database is hypothesis-driven, the dynamic hypothesis plays a fundamental role during the database design stage - especially with regard to designing the data collection, categorisation, and configuration processes. In order to do so, however, the dynamic hypothesis has to be further conceptualised.

For instance, the project's core dynamic hypothesis concerns, as noted, the functional equivalence between courts executing a mandate of judicial reviem and IAMs executing a mandate of fact-finding and compliance reviem. However, the hypothesis would require a lower level of abstraction concerning the nature of such 'functional equivalence' in order for it to 'drive' the activities of the database design and development stages. Subsequently, the project developed various conceptual models focusing on the nature of (quasi-) judicial review ('what it entails' and, importantly, 'how it is performed'), the outcomes in which it results or to which it contributes, and the dynamics between the (quasi-) judicial review body and the 'political organs' (in national constitutional systems: legislature, and executive; in the context of MDBs: MDB management, and Executive Boards of Directors). ${ }^{88}$

The development of these conceptual models was facilitated by non-legal methods such as the modelling techniques employed in systems thinking and systems dynamics $^{89}$ - in combination, however, with legal doctrinal and comparative constitutional methods. The project employed these methods to analyse landmark cases in a number of national and supranational constitutional systems, as well as the dynamics between judicial and political institutions $;^{90}$ and, to analyse a subset of IAM-practice material.

Figure 1 provides an illustration of one of the conceptual models developed in this manner. The model posits that (quasi-) judicial institutions assert and expand their de facto independence and authority vis-à-vis political institutions; but not indefinitely, as their actions are bound to trigger factors limiting further assertion and expansion (i.e. limiting 'growth') - such as 'backlash' from political institutions. On the other hand, the pro-

87. The project employs an approach that has been derived from 'evolutionary prototyping models' developed in the context of information technology (IT) design and implementation projects - see e.g. J.L. Brewer and K.C. Dittman, Methods of IT Project Management, 2nd edn. (2008), e-Book: 'Evolutionary prototyping models are initiated with initial planning and risk assessment, followed by the development of a prototype, evaluation of the prototype - and iteration of this cycle as often as required'.

88. See e.g. Naudé Fourie, above n. 58, at 33-56, 131-56 and 323-8. And see in general A. Naudé Fourie, 'The World Bank Inspection Panel's Normative Potential: A Critical Assessment, and A Restatement', LIX Netherlands International Law Review 199 (2012).

89. E.g. 'causal-loop diagrams', 'systems archetypes', and 'behavior-overtime' graphs - see in general J.D. Sterman, Business Dynamics: Systems Thinking and Modeling for a Complex World (2000); and V. Anderson and L. Johnson, Systems Thinking Basics: From Concepts to Casual Loops (1997).

90. See Naudé Fourie, above n. 58, at 59-159. longed stagnation or contraction of (quasi-) judicial independence and authority are also bound to trigger factors limiting further stagnation or retraction (i.e. limiting 'decline') - such as 'backlash' from external actors questioning the (quasi-) judicial institution's credibility. In this way, (quasi-) judicial institutions tend to fluctuate between periods of activism and restraint, but their survival ultimately requires expansion - albeit incremental expansion - along the general line of progression. ${ }^{91}$

The project employed another type of conceptual tool, the 'issue tree' - again, in combination with legal doctrinal and comparative constitutional analysis - to move the conceptual model to even lower levels of abstraction (thus, reflecting increasing degrees of detail and complexity). An excerpt from the issue tree underlying the (quasi-) judicial review model is illustrated by Figure 2.

Ultimately, the detailed issue tree underlying the (quasi-) judicial review model formed the basis for the design of the issue-view component of the IAM-practice database, with each 'branch' of the issue tree representing a distinct data category (or issue 'code'). ${ }^{92}$

For example, the model conceptualises that (quasi-) judicial institutions assert and expand their authority/ power $v i s-\grave{a}$-vis political institutions by developing and employing 'doctrines', principled approaches, or interpretative schemes - such as the margin of appreciation doctrine developed by the European Court of Human Rights. ${ }^{93}$ Where the (quasi-) judicial institution draw this 'margin' in a particular case can either restrict or expand political authority; however, the fact that it is the (quasi-) judicial institution that reviews and affirms where the margin should be drawn in particular instances illustrates that it is a form of 'judicialization' (here defined as the assertion, expansion of (quasi-) judicial authority vis-à-vis political institutions). ${ }^{94}$

Legal doctrinal analysis of MDB operational policy frameworks and the initial data-subset of IAM-practice material revealed that several operational policy provisions provided for significant degrees of 'professional judgement' or 'managerial discretion' in the application

91. Note, this reasoning is an example of the 'limits to success' systems archetype - see e.g. Sterman, above n. 89, at 111-13; and see Anderson and Johnson, above n. 89, at 59.

92. Note, the issue-view component of the IAM-practice database currently lists over 200 different 'issue-codes' or issue descriptors.

93. See e.g. Handyside v. United Kingdom, ECHR (1976), 1 EHRR 737. Also see Y. Arai-Takahashi, The Margin of Appreciation Doctrine and the Principle of Proportionality in the Jurisprudence of the ECHR (2002); and Y. Shani, 'Toward a General Margin of Appreciation Doctrine in International Law?', 16 European Journal of International Law 907 (2005).

94. See e.g. Kingsbury, above n. 58, at 332 (arguing that IAMs such as the Inspection Panel are becoming 'more like courts' due to the 'general tendency toward 'judicialization', which often appears where a triangle is formed between complainant, respondent, and institutional adjudicator, sets up a natural dynamic for the panel to enhance its jurisprudence and its own role, supported by legally oriented NGOs and potentially by some sections of Bank staff whose work such an approach vindicates'.). But see Hansungule, above n. 57, at 151. 


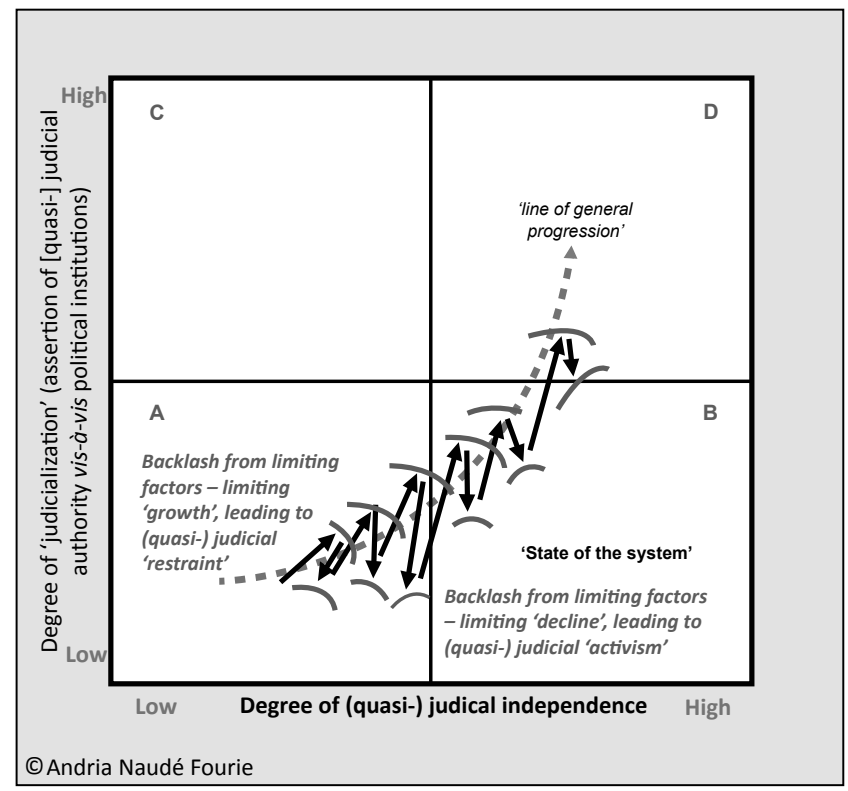

Figure 2 The (quasi-) judicial reviem model-excerpt from 'issue tree'

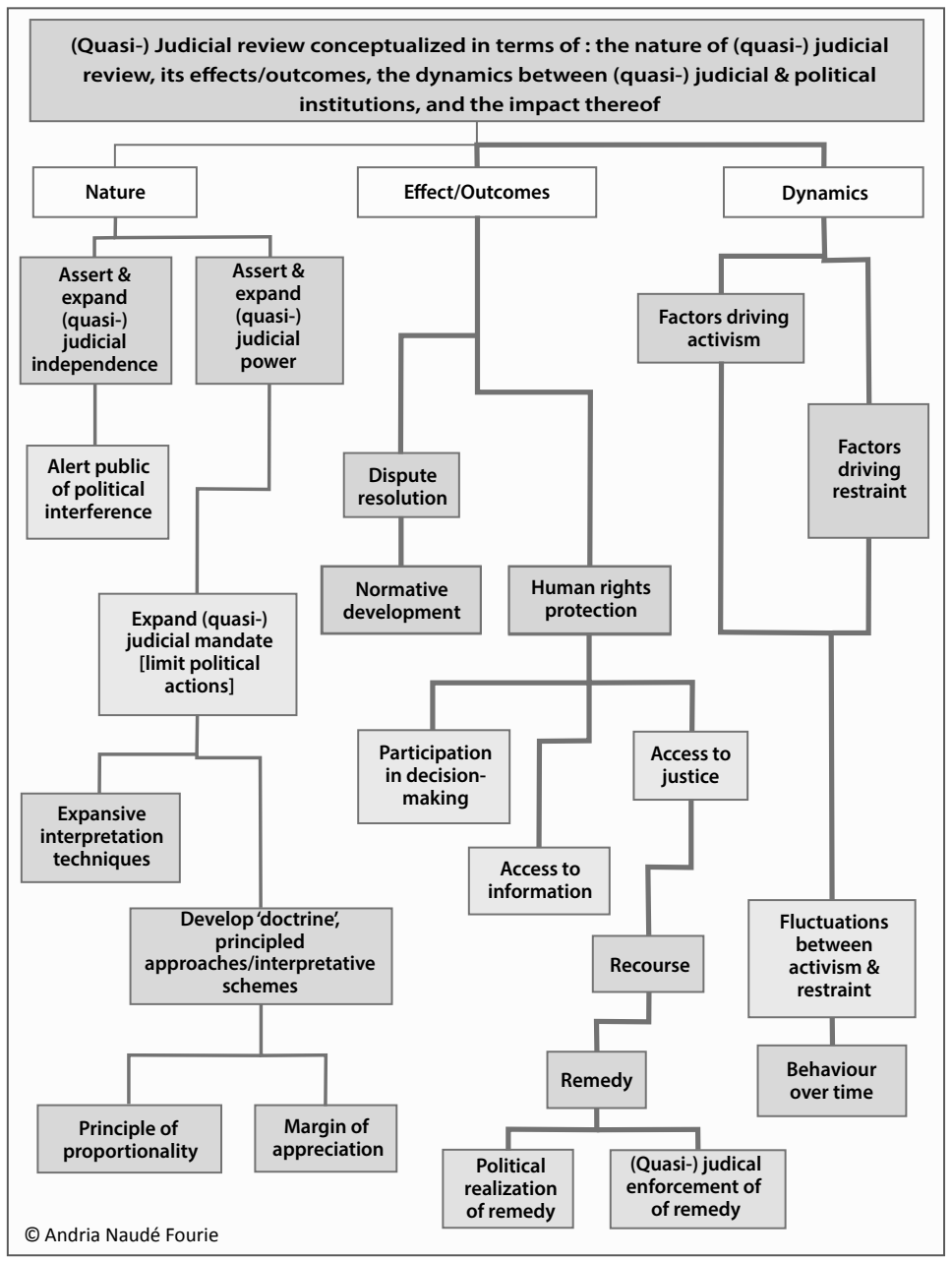

of the policies. ${ }^{95}$ Moreover, IAMs review the exercise of such professional judgement or managerial discretion in determining whether MDB actions or omissions consti-

95. See e.g. Bradlow and Naudé Fourie, above n. 45, at 30-6. Also see e.g. the World Bank's OP 4.12 (Involuntary Resettlement), para. 9 and OP 4.10 (Indigenous Peoples), para. 20 - available at: <http://www. worldbank.org/opmanual/> (last visited 31 October 2015). tuted compliance with the relevant policy. Such reviews often occur over the objection of MDB management, who appears to argue either that, due to the intrinsic nature of 'discretion', there can be no 'margin'; or, that it is up to MDB management alone to determine where 
such margins should be drawn. ${ }^{96}$ The analysis also revealed that the IAMs tend to reject these arguments thereby asserting their authority to review the exercise of professional judgement or managerial discretion and, subsequently, allowing for broader or narrower 'margins', depending on the particular circumstances. ${ }^{97}$

In Uganda: Pomer Projects, for example, World Bank management had determined that the Bank's safeguard policy on Natural Habitats (OP/BP 4.04) was not applicable to the project because, although the project would result in the 'inundation of the Bujagali Falls' (which would admittedly be 'destroy[ing] a natural habitat of significance to the people of Uganda'), the project had 'identif[ied] specific actions to offset this impact'. ${ }^{98}$ Hence, management concluded, the project would not be 'significantly converting or degrading a 'critical natural habitat' as defined in OP 4.04.' 99

In interpreting the phrase, 'in the Bank's opinion' (contained in OP 4.04), the Inspection Panel acknowledged that it indicated 'the need for and importance of the considered judgment of the Bank' on the 'crucial question' whether a project involved 'significant conversion or degradation of critical natural habitats'. ${ }^{100}$ However, the Panel argued, the inclusion of this phrase in the policy did not

imply or give Management a blank check to apply or not certain policy provisions to a specific project but rather requires Management to form and provide expressly an opinion on the issue in question, which must be consistent with the objectives of the applicable policy. ${ }^{101}$

The Panel subsequently allowed for a narrower margin of appreciation when it concluded that the project's 'flooding of the Bujagali Falls area' should have been 'regarded as a critical natural habitat for purposes of OP 4.04' since the policy 'regards inundation as a form of significant conversion or degradation' ${ }^{102}$

\subsection{Developing the Database: Legal Doctrinal Analysis Supporting Data Collection and Classification}

The database development stage executes the activities included in the processes of data collection, classification, configuration, and testing - with respect to progressively increasing datasets, until the entire dataset (i.e. of the

96. See e.g. Bradlow and Naudé Fourie, above n. 45, at 30-6.

97. Id. Also see Naudé Fourie (2012), above n. 88, at 208-10.

98. Uganda: Power Projects (2007), Inspection Panel, Investigation Report, paras. 699 and 799. Note, World Bank OP 4.04 (Natural Habitats) states: '... the Bank does not support projects that, in the Bank's opinion, involve the significant conversion or degradation of critical natural habitats' (emphases added). OP 4.04 is available at: <http://www. worldbank.org/opmanual/> (last visited 31 October 2015). Also note, all IAM-cases referenced in this article can be accessed via their respected websites - as listed above n. 4

99. Id.

100. Uganda: Power Projects (2007), Inspection Panel, Investigation Report, paras. 605-6

101. Id.

102. Id.
IAM-practice material included in the project's scope) has been incorporated. ${ }^{103}$

Legal doctrinal analysis made significant contributions with respect to the processes of data collection and categorisation (which, as noted earlier, involves assigning the appropriate 'issue-code' or descriptor to an identified data entry).

As the project's scope expanded, data collection and configuration activities were executed through the collaborative effort of a small research team that included legal researchers schooled in legal doctrinal analysis and familiarised with the atypical legal content and format of IAM-case material. At this point, the conceptual models developed during the design stage with the assistance of legal doctrinal analysis, also served to facilitate such collaboration.

In other words, as the research team systematically worked through the source data (which, as noted, consisted primarily of text) - guided by the dynamic hypothesis and its supporting conceptual models - the team could identify a potential data entry by employing legal doctrinal analysis, even as it was not immediately clear what the data entry signified, or with which issuecode(s) the data entry should be configured within the database. ${ }^{104}$ The team would regularly review recently collected and configured data, which would not only ensure data quality but would often also result in further refinement of the conceptual model and the database design. ${ }^{105}$ In this way, through the 'shared surface' offered by normativity, the team could interact by reasoning from and through the norms contained in the data source material. ${ }^{106}$

To highlight one example, fairly early on during the database development stage, a particular data entry from the Inspection Panel's China: Qinghai investigation was identified and linked to the 'margin of managerial discretion' issue, discussed earlier. The data entry concerned the World Bank's application of its policies on Environmental Assessment and Involuntary Resettle-

103. On the approach followed to ensure data quality, see above, n. 87 . Also note, the research project progressively expanded its scope by including additional IAMs; however, the project included the entire body of cases of IAMs in scope - as opposed to a data subset or selected cases.

104. Note, it is common for a data entry (i.e. an extract from IAM-practice material) in the issue-component of the IAM-practice database to be associated with multiple issue-codes due to the relationships among various issues.

105. Note, the project adopted an approach by which the (initial) inclusion of 'false positives' was considered preferable above the exclusion of 'false negatives' - i.e. when in doubt, a team member would include a data entry and flag it for discussion; whereupon a final determination would be made during the research team's regular data review meeting.

106. Brunnée and Toope, above n. 16, at 7. And see Boisson de Chazournes, above n. 49, at 187-8, arguing that the establishment of IAMs at MDBs 'reflects the evermore urgent need to build 'public spaces,' in the meaning attributed to that concept by the philosopher Jürgen Habermas' i.e. public spaces that can facilitate the creation of 'unusual connections between partners of different stature, who need to exchange information, work together and even negotiate'; and that citizen-driven can be viewed as 'a formalization of the type of interrelation contemplated by Habermas' model,' because their practice 'connects individuals with the very core of the international decision-making process within this institution. 
ment, with the Inspection Panel arguing that these policies could not

possibly be taken to authorize a level of 'interpretation' and 'flexibility' that would permit those who must follow these [policies] to simply override the portions of the [policies] that are clearly binding. ${ }^{107}$

Moreover, the Panel added, World Bank management 'had an obligation'

to satisfy itself not only that the process and procedures mandated by the policies had been followed, but also that the work under review met professionally acceptable standards of quality. ${ }^{108}$

'In other words,' the Panel concluded, 'both process and quality were essential components of compliance'. 109 The Inspection Panel elaborated that a 'process' approach could mean that 'even a one-page environmental assessment of a major project could ... be in compliance if it passed the desks of, and was checked off by, the appropriate persons at the appropriate times in the decision process'.110

With this example at hand, data entries reflecting a similar line of reasoning in Inspection Panel cases preceding the 1999 Qinghai case were identified. In India: NTPC Pomer, for instance, the Panel commented that the project's resettlement and rehabilitation components 'appear[ed]' to be compliant 'at least on paper, with the Bank's [policy on Involuntary Resettlement] and were [therefore] cleared by the Bank's Legal Department and Environmental Specialists'; 11 however, because the 'loan was processed so rapidly', the Resettlement Action Plans were only 'completed immediately before the project was presented to the Bank's Board' for approval. ${ }^{112}$ Hence, the Panel concluded, 'there was no time to ensure that essential mechanisms and preconditions, such as State Government commitment, capacity of implementing agency, etc. mere in place or adequate'. ${ }^{113}$

As the project progressed, more examples of this nature were also identified in later Inspection Panel cases. For example, in Colombia: Cartagena Water Project, concerning the consideration of project design alternatives, the Panel noted 'that the appointment of a panel of experts to review the technical work in the feasibility study and the design of the Project [was] consistent with Bank policies, particularly OD 4.01 paragraph 13,' but the Panel also commented that it was 'not convinced that there was a sufficiently thorough analysis of alternatives before a decision on the [marine sewage] outfall was

107. China: Western Poverty Reduction Project (1999), Inspection Panel, Investigation Report (Executive Summary), para. 11.

108. China: Western Poverty Reduction Project (1999), Inspection Panel, Investigation Report, paras. 180-6.

109. Id.

110. Id., at para. 39

111. India: NTPC Power Generation Project (1997), Inspection Panel, Investigation Report, para. 19 (emphasis added).

112. Id. (emphasis added).

113. Id. (emphasis added). made'. ${ }^{114}$ Whereas in Albania: Pomer Sector, on whether two meetings held with project-affected people in 2003 could be considered as the two EA [environmental assessment] consultations required by the Bank for a Category A [i.e. high risk] project' (as argued by Bank management), the Inspection Panel pointed out that these meetings took place well after the borrower government 'had approved the siting for the Project [concerning the location construction of a thermal power plant]'. 115 'This form of EA consultation,' the Panel concluded, 'created the appearance of consultation and of consistency with the OP,'

but in reality was a 'pro-forma move,' not a genuine consultation. [The two meetings] contributed nothing to improving project selection, siting, planning or design of the Project, and was not consistent with timing required by the $\mathrm{OP}[4.01$ on $\mathrm{EA}] .{ }^{116}$

By employing legal doctrinal analysis, the project came to the conclusion that these examples were indicative of a particular interpretive scheme developed and employed by the Inspection Panel. An interpretative scheme, in other words, that emphasises compliance with both the procedural (process) and substantive (quality) normative elements contained in the operational policies.

The project subsequently identified data entries that demonstrate the normative development occurring as a result of the Panel's employment of this interpretative scheme, as well as others - especially in areas concerning access to information, participation in decision-making, and access to justice, which, in turn, are critical for the realisation of sustainable development and, arguably, for 'mainstreaming' human rights in development practice. $^{117}$

Finally, by employing legal doctrinal methods in concert with other conceptual and analytical tools, the project

114. Colombia: Cartagena Water Project (2004), Inspection Panel, Investigation Report, para. 77 (emphasis added).

115. Albania: Power Sector (2007), Inspection Panel, Investigation Report, paras. 343-44. Also see e.g. India: Coal Sector (2001), Inspection Panel, Investigation Report, paras. 348-9 (the Panel arguing that the project's Indigenous Peoples Development Plans were 'disconnected, [had] little depth, [were] just marginal and, on the whole, [did] not reflect a real 'felt' need'. E.g. the Panel expressed its concern 'that there has been no concentration on long-term projects such as literacy and numeracy classes, maternal and child health, and self help groups'). And see India: Mumbai Urban Transport (2004), Inspection Panel, Investigation Report, para. 725 (the Panel noted that while Management had 'early on reminded the Borrower on the need to form and register [replacement] housing cooperatives, it failed to adequately supervise this aspect of the Project .... in that it focused only on [the housing cooperatives'] registration and did not consider their operational capacity and effectiveness').

116. Id. (emphasis added).

117. I.e. the so-called 'Rio Declaration Principles', as reflected in the declaration adopted in 1992 during the United Nations Conference on Environment and Development, see <http://www.unep.org/Documents. multilingual/Default.asp?DocumentID=78\&ArticleID=1163> (last access ed 31 October 2015). On the relationship between public participation and human rights protection see e.g. Bradlow and Chapman, above $n$. 49; and see the Inspection Panel's comments in the Chad: Petroleum case, below n. 124 
identified various forms of normative development. ${ }^{118}$ Including, for instance, normative development that strengthens the 'obligatory nature' of the operational policies; ${ }^{119}$ enhances the degree of 'precision' or specificity of 'particular policies provisions'; 120 clarifies, as well as elaborate, on the relationship between MDB operational policy frameworks and the international legal system (for instance, by referencing international legal standards, or by 'reading' certain international legal standards 'in' (to) the policies); ${ }^{121}$ as well as a form of normative development that links the restrictive or restraining elements contained in the policies (such as those aimed at avoiding or mitigating harm) to other elements aimed at enabling the realisation of particular institutional aims. ${ }^{122}$

For example, as the IFC's Compliance Advisory Ombudsman Commented in Chile: Empresa Electrica Pangue:

Business confidentiality is enshrined in IFC's disclosure policy. However, it may be interpreted expansively or minimally. The CAO has been urged not to judge the actions of IFC staff and management in the early and mid '90s by the standards of today, 2003. But the discussion of disclosure relates to recent and present activities. Communities consider that they have the right to know if the World Bank Group is exiting a deal, especially when they understand that the exit is predicated upon conditions being met by the sponsor that directly affect them. They want to have access to independent monitoring and verification reports of social and environmental issues which directly concern and impact them. They have a right to know the substance of negotiations that are being undertaken on their behalf. They have a right to know the operational and emergency planning that may impact their lives and security. They have a right to expect that a project of the World Bank Group will at the very least protect them, to the

118. See Bradlow and Naudé Fourie, above n. 45, at 40-57. Note, data gathered by employing legal doctrinal methods in concert with other conceptual and analytical tools informed different conclusions about the normative contribution of IAMs than those reached by international legal scholars arguing that IAMs have not fulfilled their normative potential. See e.g. C. Tan, 'Mandating Rights and Limiting Mission Creep: Holding the World Bank and the International Monetary Fund Accountable for Human Rights Violations', 2 Human Rights and International Legal Discourse 97 (2008)

119. Id. Illustrated by examples from IAM-practice concerning the 'margin of managerial discretion', noted earlier - see e.g. Indonesia: Wilmar Group 01 West Kalimantan (2007), Compliance Advisor Ombudsman, Audit Report, para. 2.8.3; and Bolivia: Comsur V-01 Bosque Chiquitano (2003), Compliance Advisor Ombudsman, Assessment Report, at 10.

120. Id. See e.g. Ecuador: Mining Development \& Environmental Control Technical Assistance Project (1999), Inspection Panel, Investigation Report, paras. 52, 57 \& 103; and see Peru Agrokasa-01/Ica (2009), 121. Id Compliance Advisor Ombudsman, Audit Report, para. 4.1.1.

122. See e.g. Paraguay/Argentina: Yacyretá Hydroelectric Project (2002), Inspection Panel, Investigation Report, paras. 405 and 408, commenting, with respect to its findings of significant non-compliance with the Bank's policy on Involuntary Resettlement, that the project 'demonstrate[d] that taking short-cuts with the Bank's safeguard policies is counterproductive for all concerned' (emphasis added). extent possible, from negative development impacts and, where unintended impacts occur, that mitigation measures are discussed and agreed with them. These rights and issues of respect are not ones that evolve as policies evolve; they are fundamental. They were in 1993, and they are in 2003. The policy framework with which IFC works to ensure that they are upheld has evolved, but IFC did not deal transparently with the people affected by this project. ${ }^{123}$

Or, as the Inspection Panel argued in Chad: Petroleum, '[g]iven the world-wide attention to the human rights situation in Chad ... and the fact that this was an issue raised in the request for inspection by a Requester'

who alleged that there were human rights violations in the country, and that he was tortured because of his opposition to the conduct of the project, the Panel was obliged to examine the situation of human rights and governance in the light of Bank policies. We are convinced that the approach taken in our Report, which finds human rights implicitly embedded in various policies of the Bank, is within the boundaries of the Panel's jurisdiction. ... Nevertheless, the Panel takes issue with Management's narrow interpretation of the Bank's position on human rights [i.e. that the Bank's mandate excluded civil and political rights; or was limited to socio-economic rights]. ... The Bank policies on consultation, among others, presume a basic respect for human rights. There was a period in Chad when consultations with affected groups were conducted in the presence of armed gendarmes. This was hardly compatible with the Bank policies concerned. ... Mr. Chairman, perhaps this case should lead the Board to study the wider ramifications of human rights violations as these relate to the overall success or failure of policy compliance in future Bankfinanced projects. ${ }^{124}$

Examples such as these demonstrate how law attains its place in transnational regulatory governance contexts through 'thin' (procedural) normative commitments (in this instance, as represented by the MDBs' adoption of operational policies frameworks and their establishment of citizen-driven IAMs to aid in the enforcement of these frameworks) and also how law secures and expands its place in these contexts by facilitating the realisation of 'thick' (substantive) normative commitments - notably, by means of the 'dispute resolution triad' formed between individual claimants, MDB Management (the 'respondents'), and IAMs (with Executive Board usually acting as final arbitral body). ${ }^{125}$

123. See Chile: Empresa Electrica Pangue SA 02 Upper Bio-Bio Watershed (2002), Compliance Advisor Ombudsman, Assessment Report, at 24 (emphasis added).

124. See Chad: Petroleum (2001), Inspection Panel, Inspection Panel Chair's Address to Board on occasion of Board's adoption of the Panel's Investigation Report, para. 8 (emphases added.)

125. Brunnée and Toope, above n. 16, at 86; and see Shapiro and Stone Sweet, above n. 60. 


\section{Conclusion}

Perhaps the first conclusion to be drawn from the experiences with developing and deploying an advanced legal-interdisciplinary methodology to study the practice of IAMs at MDBs - as discussed in this article - is that they are not so different from the experiences of 'conventional' legal doctrinal research projects.

After all, most of the project's source data is text (albeit a-typical legal text), whereas the claims filed before IAMs 'arise out of the conflicts of social practice', ${ }^{126}$ as is true for legal cases, and the resolution of such claims require the deployment of interpretative techniques and principled or reasoned interpretative schemes similar to those employed by courts. ${ }^{127}$

Moreover, once legal researchers overcome the methodological obstacles presented by the particular format and content of IAM-practice material - which include an ambiguous and inconsistent use of legal terminology (by claimants, MDB management, Board of Executive Directors, and IAMs alike) ${ }^{128}$ - they intuitively know 'what to do with the data'. ${ }^{29}$

In a way, these observations confirm Vick's argument that '[d]octrinalism' or 'the traditional doctrinal approach to legal questions' 'remains the benchmark against which legal academics define themselves and their work'. ${ }^{130}$ It certainly served as 'the point of departure' for this project. ${ }^{131}$ The experiences with this project also support Feldman's argument that legal doctrinal analysis is something that legal researchers 'constantly' and intuitively $d o .{ }^{132}$ However, Feldman remains sceptical of the value of employing non-legal methods, arguing that legal-interdisciplinary researchers invariably 'return to the well' because they are 'constantly disappointed' in 'some new science' that fails to 'provide answers to law's dilemmas'. ${ }^{133}$

And this is probably where the experiences of this project deviate most from those to which Feldman alludes.

Legal doctrinal methods occupy a prominent place within this research methodology because they make a distinct and significant contribution towards facilitating inquiry as well as collaboration within the research team. Legal doctrinal analysis certainly enabled the

126. S. Taekema, 'Relative Autonomy: A Characterisation of the Discipline of Law', in B. Van Klink and S. Taekema (eds.), Law and Method: Interdisciplinary Research into Law (2011), at 45 - noting that '[a]ll standard sources for lawyers are texts'.

127. See e.g. Bradlow and Naudé Fourie, above n. 45, at 41-57.

128. Terms such as 'rights', 'interests', 'legalistic', 'recourse', 'redress', 'reme$\mathrm{dy}^{\prime}$, and 'jurisdiction' are often employed in IAM-practice material without any explanation as to their meaning; whereas legal doctrinal analysis of data entries containing such terms often indicates that their meaning often depends on the actor employing them. In this regard, see Naudé Fourie, above n. 58, at 1-3.

129. For additional examples of methodological obstacles to studying IAMmaterial, see Naudé Fourie, at Id

130. Vick, above n. 25, at 188

131. Id.

132. See R. Feldman, 'Law's Misguided Love Affair with Science', 10 Minne133. Id identification of patterns and structures in the data that mere textual analysis could not have done.

But while legal doctrinal methods may have constituted the 'right tools' for particular 'jobs', they have not been the only conceptual and analytical instruments of value in the project's methodological toolkit. In other words, the project employs legal doctrinal methods and legal theories, but not because non-legal methods and theories fail to live up to expectation. Nor, for that matter, does the project employ non-legal methods and theories because legal methods and theories 'disappoint'. ${ }^{134}$

Instead, the project employs a combination of legal and non-legal methods and theories in order to realise specific research objectives, irrespective of whether these objectives are predominantly legal or non-legal. The development of conceptual models, for example, which fulfil several important functions within this project, could not have been done by relying solely on one instrument in the methodological toolkit. The same could be said about designing and developing the IAMpractice database.

This is not to say, of course, that the distinctions between legal and non-legal methodological elements cease to exist, or that they become entirely insignificant. In fact, in order to integrate different questions, theories, and methods - as (legal-)interdisciplinary researchers have to do, albeit in varying degrees - it is crucial to understand what each element has to offer, what it cannot offer, and how they might best complement each other. Integration, as mentioned, remains both a 'core feature and major challenge of' interdisciplinary research, ${ }^{135}$ but the experience with this research project indicates that the integration of legal doctrinal methods does not present any more or less of a challenge than those of other elements. Legal doctrinal methods have, however, proved to be a synergetic fit with the 'recursive approach to problem solving' underlying this project. ${ }^{136}$ One of the broader problems considered by this project concerns the place of law in transnational regulatory governance contexts - here, specifically with regard to the transnational development context involving MDBs and other co-financiers, MDB (donor and borrower) member states, (public and private sector) project implementing agencies, project-affected people, and civil society actors.

This article concludes that the IAM-practice research project has been able to generate new perspectives on this matter firstly, because it has been based in a constructivist, interactional (as opposed to a positivistic) conception of legal normativity. ${ }^{137} \mathrm{~A}$ second reason concerns the project's focus on IAM and MDB practice, as

134. Id.

135. Hirsch Hadorn et al., above n. 19, at 431.

136. Id.

137. See Section 1.1. 
opposed to being limited to institutional aspects. ${ }^{138}$ Thirdly, facilitated by the design and development of the IAM-practice database, the project's scope could include the entire dataset, as opposed to a mere subset of IAM-practice or selected case studies. ${ }^{139}$ And, finally, because of its employment of legal doctrinal methods, in combination with other methods and theories, the project could conclude that law has a distinct place in transnational regulatory governance contexts - that is, if you know where to look for law, and how to find it.

138. I.e. matters such as IAM-mandates, processes, functions, independence - e.g. as reflected in their constitutive documents, operating procedures, and MDB operational policy frameworks, which form the basis of IAMreview mandates. For examples of such contributions, see e.g. R.E. Bissell, 'Institutional and Procedural Aspects of the Inspection Panel', in G. Alfredsson, and R. Ring (eds.), The Inspection Panel of the World Bank: A Different Complaints Procedure (2001) 107; and see E. Baimu and A. Panou, 'Responsibility of International Organizations and the World Bank Inspection Panel: Parallel Tracks Unlikely to Converge?', in $\mathrm{H}$. Cissé, D.D. Bradlow \& B. Kingsbury (eds.), The World Bank Legal Review: International Financial Institutions and Global Legal Governance (2011), e-Book. Note, this article does not dispute the value of such contributions; it merely argues that there are not enough empirical contributions in this particular area of study.

139. See e.g. S. Ananthanarayanan, 'A Crippled Inspection Panel', India Together (2004), available at: <http://www.indiatogether.org/2004/jul/ hrt-wbinspect.htm> (last visited 31 October 2015); and see R. Oleschak-Pillai, 'Accountability of International Organisations: An Analysis of the World Bank's Inspection Panel', in J. Wouters, E. Brems, S. Smis \& P. Schmitt (eds.), Accountability for Human Rights Violations by International Organisations (2010), at 406. 